\title{
A Plummer Vinson Syndrome Related to Pregnancy and Revealing Oesophageal Tumor
}

\author{
Moussa Diallo*, Djibril Diallo, Astou Coly Niassy Diallo, Fatoumata Bineta Diallo, Aminata Niass, Cyr Espérence \\ Gombet Koulimaya and Abdoul Aziz Diouf
}

Service de Gynécologie-Obstétrique, Centre Hospitalier National de Pikine, Sénégal

Submission: January 18, 2019 ; Published: February 07, 2019

*Corresponding author: Moussa Diallo, Service de Gynécologie-Obstétrique, Centre Hospitalier National de Pikine, Sénégal

\begin{abstract}
Still called sideropenic dysphagia, Plummer-Vinson syndrome was first described by Donald Ross Paterson and Adam Brown-Kelly in 1919, then by Plummer-Vinson, to whom he owes his other current name known mostly to the British. It is indeed to these last two researchers that its association with a post-cricoid carcinoma has been demonstrated for the first time. It is a rare condition characterized by a symptomatic triad associating high dysphagia, hypochromic microcytic anemia and an oesophageal ring. Its frequency is very poorly evaluated and seems to occur in adult women between 40 and 80 years. Its pathogenesis is just as poorly known, but anemia, vitamin deficiencies and immunological factors are constant factors. We report here a case of this syndrome in a 34-year-old patient with 32 weeks of amenorrhea.
\end{abstract}

\section{Introduction}

Still called sideropenic dysphagia, the Plummer-Vinson syndrome was first described by Donald Ross Paterson and Adam Brown-Kelly in 1919, then by Plummer-Vinson to whom it owes its other current name known mainly to the British $[1,2]$. It is indeed to these last two researchers that its association with post-cricoid carcinoma was first demonstrated [3,4]. It is a rare condition characterized by a symptomatic triad combining high dysphagia, microcytic hypochrome anemia and an esophageal ring. Its frequency is very poorly assessed and appears to occur in adult women between 40 and 80 years of age. Its pathogenesis is also poorly known, but anaemia, vitamin deficiencies and immunological factors are constant factors. Pregnancy can therefore be considered as a favourable ground for its occurrence. During pregnancy, its symptomatology may be confused with sympathetic signs and only a fibroscopy can correct the diagnosis. In addition, this syndrome is one of the risk factors for cancer of the upper digestive. tract, which makes it very serious and requires close and prolonged surveillance. We report here a case of this syndrome in a 34-year-old female patient who was followed since the beginning of pregnancy for severe gravidic vomiting and in whom it was associated with genuine squamous cell carcinoma of the lower third of the esophagus [5].

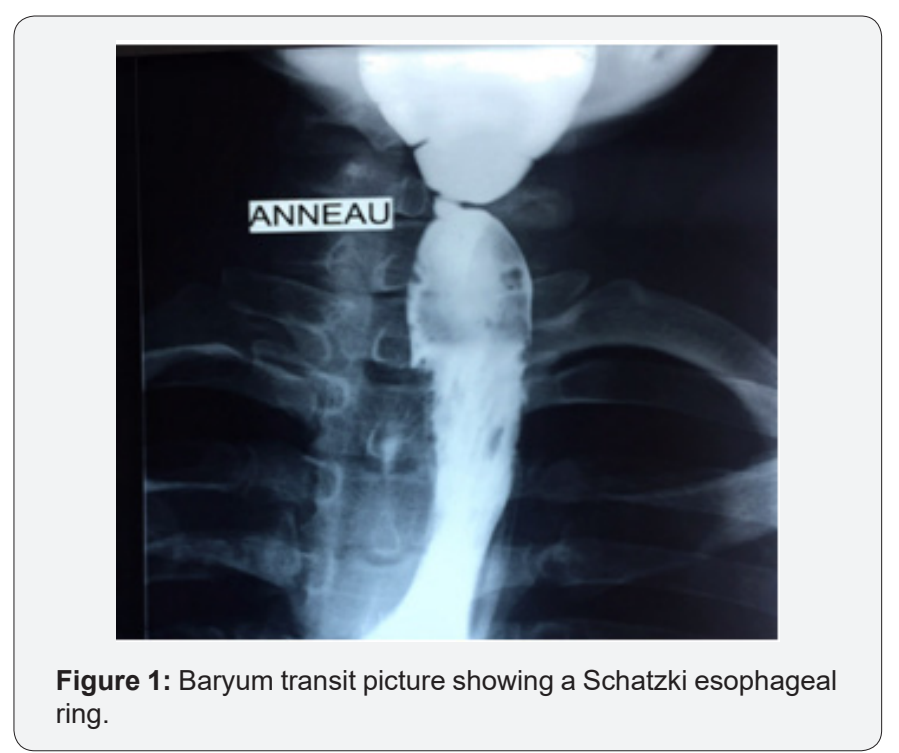

\section{Observation}

Patient of 27 years old second gesture, with fetal death in utero in detention during the first pregnancy, admitted for total dysphagia (with solid and liquid food) with a progressive pregnancy at 32 weeks of amenorrhea. The obstetrical 
examination diagnosed severe pre-eclampsia with hypertension at $170 / 110 \mathrm{~mm} \mathrm{Hg}$ and severe anemia at $4 \mathrm{~g} / \mathrm{dl}$ microcytarian hypochrome with hemoconcentration (hematocrit at 52\%). An obstetrical ultrasound performed found intrauterine growth restriction and the estimated fetal weight of $1400 \mathrm{~g}$. In addition, an esophageal-gastro-duodenal transit with barium revealed a ring of strangulation at the upper $1 / 3$ of the esophagus at the sixth cervical vertebra and a narrowing of its lumen strongly suspected of an esophageal tumor (Figure 1). Endoscopic exploration found a Schatzki Ring $18 \mathrm{~cm}$ from the dental arches suggesting Plummer-Vinson syndrome in this painting. The secondary dilation performed had made it possible to visualize a friable budding tumor over $7 \mathrm{~cm}$ of circumferential height with invasion of the subcardial region. Histological examination of the biopsies performed was in favour of a differentiated, mature and infiltrating squamous cell carcinoma of the esophagus. The CT scan found a tumour of the chest and abdominal esophagus $8.5 \mathrm{~cm}$ high with no evidence of secondary location or oeso-tracheal fistula (Figure 2). The patient had a cesarean section that resulted in the birth of a live male newborn weighing $1500 \mathrm{~g}$. The patient was treated by radio chemotherapy. The consequences were unfavorable and the patient died 3 months after the start of treatment (Figure 3).

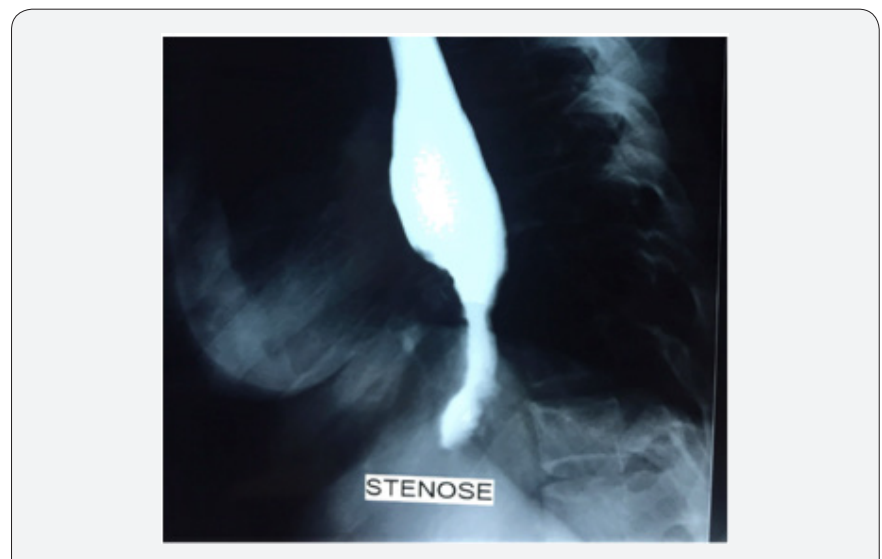

Figure 2: TOGD picture showing a stenosis of the lower third of the esophagus below the Schatzki ring.

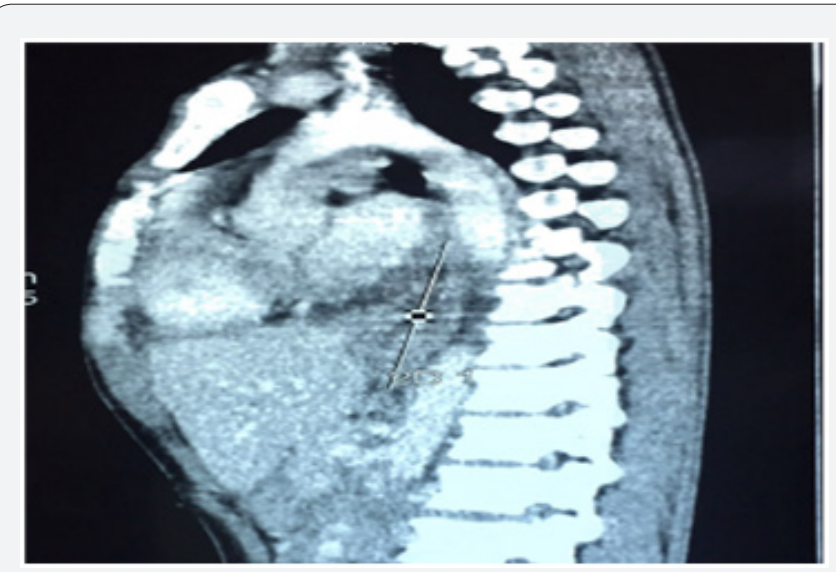

Figure 3: CT scan showing an esophageal tumor.

\section{Discussion}

For several decades, the consequences of an iron deficiency on the digestive mucosa have been widely described. During pregnancy, iron demands increase and can aggravate pre-existing anemia or precipitate a borderline condition. In Africa and other populations, certain harmful dietary behaviours described as « PICA syndrome » or disease that associate to varying degrees the consumption of certain products without any energy value $[5,6]$.

In addition, some digestive diseases, such as dysphagia and vomiting, can be misused and treated as sympathetic signs of pregnancy. This requires a rigorous exploration of any digestive disorder and therefore a digestive endoscopy, especially beyond the first trimester. Plummer Vinson's syndrome is a rare condition that combines dysphagia, iron deficiency anemia and a membrane in the esophageal mouth. It exposes to a risk of hypopharyngeal.

Carcinoma in 3 to $15 \%$. Its association with carcinoma of the oral cavity, the middle oesophagus or the stomach is exceptional. This syndrome can occur in both women and men, but is most common in Caucasians [7]. In Africa, the occurrence of pregnancy and certain eating behaviours can be real risk factors for pregnancy in the absence of martial supplementation. Although several theories about its genesis have been mentioned, iron deficiency seems to be the most accepted. During martial deficiency, the decrease in the number of mitochondria in the muscle fibers as well as the decrease in the energy metabolism of the cells of the digestive tract due to the degradation of their capital into irondependent oxydative enzymes weakens the ability to exercise and leads to an anomaly in esophageal peristalsis causing the formation of a fold or diaphragm [8,9]. Indeed, the incidence of Plummer Vinson syndrome is high in premenopausal women with an increased need for iron during pregnancy, lactation and also during menstruation, but the incidence is declining in the population with good and improving nutritional status. The diagnosis of this condition is based on the occurrence of persistent organic dysphagia. Endoscopy, which should be mandatory or better, an oeso-gastro-duodenal transit with a contrast agent allows to highlight a Schatzki ring and to look for other associated lesions [10]. Management during pregnancy will depend on the term. Our patient received a prophylactic cesarean section and radiotherapy. However, his prognosis remains appalling in this young field with a late diagnosis.

\section{Conclusion}

Plummer Vinson syndrome is a reality in Africa. Pregnancy and certain eating behaviours may contribute to its occurrence. Endoscopy should be the rule in any stubborn dysphagia not only for diagnosis but also to look for associated lesions.

\section{References}

1. Plummer HS, Vinson PP (1921) Cardiospasm. Medical clinical North América 5: 355-369.

2. Paterson K (1919) A clinical type of dysphagia. The journal of Laryngology and Otology 34(8): 289-291. 
3. Kitabayachi K, Akiyama T, Tomita F, Saitoh H, Kosaka T, et al. (1998) Gastric cancer occuring in a patient with Plummer-Vinson Syndrome Report of a case. Surg Today 28(10): 1051-1055.

4. Ahlbom HE (1936) Simple achlorhydric anemia. Plummer Vinson Syndrome and carcinoma of the mouth, pharynx and esophagus in women. Observations at Radiumhemm et, Stockholm. Br Med J 2(3945): 331-333.

5. Lambert V (2014) Géophagie et grossesse: connaissances actuelles et gestion. Expériences cliniques d'un service d'obstétrique en Guyane française. Journal de Gynécologie Obstétrique et Biologie de la Reproduction 43(7): 496-503.

6. Studziński Z1, Grzybowski Z (1999) Giant trichobezoar in the stomach coexisting with pregnancy: a case report. Ginekol Pol 70(11): 830-834
7. Wynder E, Hultberg S (1957) Environmental factors in cancer of the upper alimentary tract; A Swedish study with special reference to Plummer-Vinson Syndrome. Cancer 10(3): 470-487.

8. Okamura H, Tsutsumi S (1998) Esophageal web in Plummer Vinson Syndrome. Laryngoscope 98(9): 994-998.

9. Dantas RO, Villanova M (1993) Esophageal motility impairment in Plummer Vinson Syndrome. Correction by iron treatment. Dig Dis Sci 38(5): 968-971.

10. Ngelfinger FJ, Kramer P (1953) Dysphagia produced by a contractile ring in the lower esophagus. Gastroenterology 23(3): 419-430.

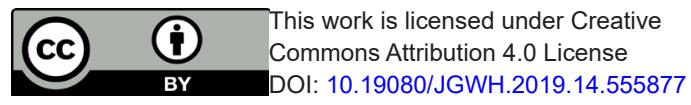

Your next submission with Juniper Publishers will reach you the below assets

- Quality Editorial service

- Swift Peer Review

- Reprints availability

- E-prints Service

- Manuscript Podcast for convenient understanding

- Global attainment for your research

- Manuscript accessibility in different formats ( Pdf, E-pub, Full Text, Audio)

- Unceasing customer service

Track the below URL for one-step submission https://juniperpublishers.com/online-submission.php 